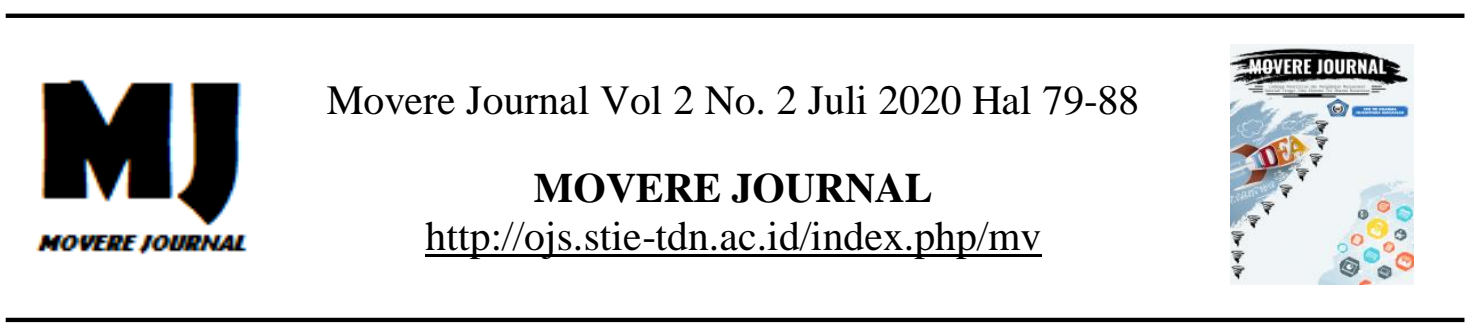

\title{
AKUNTANSI SYARIAH: SUATU PENGANTAR ALIRAN PEMIKIRAN
}

\author{
Rizky Iman Perkasa Wardoyo Putra \\ (Universitas Islam Alauddin Makassar)
}

\begin{abstract}
Abstrak : Keresahan dan kekhawatiran masyarakat Indonesia terhadap sistem praktik ekonomi konvensional membuat sebuah hasil yang menjadi landasan perkembangan ekonomi syariah di Indonesia dengan berdirinya Bank Muamalat Indonesia pada tahun 1991 dan beroperasi di tahun 1992. Dalam perjalanan tersebut, entitas usaha yang menjalankan praktik syariah dalam transaksi laporan keuangannya membutuhkan pencatatan dengan menggunakan metode berdasarkan prinsip Islam pula. Praktik pencatatan laporan keuangan entitas syariah ini menggunakan metode pencatatan berdasarkan kepercayaan terhadap aliran akuntansi syariah yang telah beredar. Jenis penelitian ini menggunakan metode kualitatif dengan melakukan pendekatan studi literatur dari data sekunder, di mana data sekunder merupakan data yang diperoleh dari penelitian-penelitian yang telah dilakukan peneliti terdahulu dan sumber referensi lainnya.
\end{abstract}

Kata Kunci : aliran, akuntansi, syariah, pencatatan

\section{PENDAHULUAN}

Kemunculan sistem syariah di Indonesia dilandaskan oleh semakin berkembangnya kesadaran masyarakat muslim terhadap ketidakpuasan mereka terhadap perekonomian berbasis konvensional dan riba. Setelah terjajah oleh prinsip ekonomi konvensional selama berpuluh tahun, masyarakat muslim Indonesia mulai mencari bentuk perekonomian yang sesuai dengan ajaran kepercayaan mereka. Mereka yang menginginkan adanya sistem syariah dalam perekonomian Indonesia percaya bahwa dengan mengikuti perintah Allah swt, maka kehidupan dunia dan akhirat mereka dijamin akan diberkahi.

Kekhawatiran masyarakat muslim
Indonesia untuk terlepas dari belenggu riba dan perekonomian konvensional akhirnya menemukan jawaban ketika Bank Muamalat Indonesia mulai mengibarkan sayapnya di bidang perekonomian syariah pada tahun 1991 dan beroperasi secara penuh di tahun 1992. Pendirian Bank Muamalat Indonesia sebagai bank syariah pertama di Indonesia ini tidak lepas dari peran serta Majelis Ulama Indonesia, Ikatan Cendekiawan Muslim Indonesia, pemerintah Indonesia, dan dukungan dari masyarakat Indonesia sendiri saat itu. Bank Muamalat Indonesia menjadi tonggak sejarah kebangkitan perekonomian syariah di Indonesia dan menjadi tolak ukur acuan kemunculan

(C) 2020 STIE TDN. All rights reserved

Corresponding Author: 80500218038@uin-alauddin.ac.id 
bank-bank syariah lain di Indonesia.

Kinerja bank syariah merupakan indikator penting untuk menentukan nilai dan posisi bank syariah tersebut di dunia perbankan dan di mata masyarakat. Setelah bank syariah atau perusahaan berbasis syariah di Indonesia berdiri, maka tentu saja perusahaan tersebut memerlukan sebuah laporan keuangan sebagai bentuk pertanggungjawaban kepercayaan masyarakat terhadap perusahaannya. Laporan keuangan sendiri merupakan hasil akhir dari suatu proses akuntansi yang tujuannya memberikan informasi tentang posisi keuangan, kinerja, dan arus kas entitas syariah yang bermanfaat bagi semua kalangan pengguna laporan dalam rangka membuat berbagai keputusan ekonomi.

Dalam perkembangan akuntansi syariah di Indonesia, tidak lepas dari pengaruh dan imbas berbagai pemikiran. Adanya aliran pemikiran akuntansi syariah ini bersumber dari lajunya perkembangan lembaga keuangan syariah dan perusahaan berbasis syariah serta keinginan kuat para sarjana muslim untuk menghadirkan konsep akuntansi yang lahir dari agama Islam sendiri tanpa campuran pemikiran akuntansi konvensional. Salah satu pendekatan untuk menyatukan aliran pemikiran di akuntansi syariah adalah dengan menemukan satu konsep yang tepat untuk menghubungkan pendekatan deduktif dan induktif dalam teori-teori akuntansi syariah yang telah ada.

\section{TELAAH LITERATUR DAN PENGEMBANGAN HIPOTESIS}

\section{Ciri Pelaporan Keuangan Akuntansi Syariah}

Berikut adalah ciri-ciri pelaporan keuangan akuntansi dalam bingkai syariah:

1. Dilaporkan Secara Benar
Pencatatan keuangan suatu usaha adalah tahap awal dalam menjalankan tahapan akuntansi. Dengan melakukan pencatatan, pelaku usaha akan mengetahui jumlah keuntungan yang diperoleh dan jumlah kerugian yang dialami selama periode tertentu. Pencatatan ini berfungsi untuk dapat menentukan strategi yang harus dilakukan ke depannya agar mendapatkan keuntungan, sehingga pencatatan dan pelaporan keuangan harus dilakukan dengan benar dan sungguh-sungguh.

Allah swt berfirman dalam QS Yusuf/10: 5 yang berbunyi:

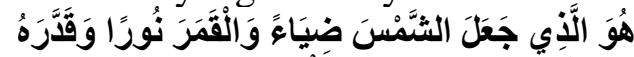

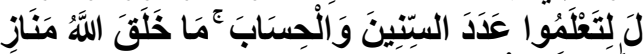

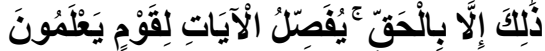
diyā'aw wal-qamara nuraw wa qaddarahu manāzila lita'lamu 'adadassinina wal-hisāb, mā khalaqallāhu żālika illā bil-ḥaqq, yufașșilul-āyāti liqaumiy ya'lamun.

Dialah yang menjadikan matahari bersinar dan bulan bercahaya, dan Dialah yang menetapkan tempattempat orbitnya, agar kamu mengetahui bilangan tahun dan perhitungan (waktu). Allah tidak menciptakan demikian itu melainkan dengan benar. Dia menjelaskan tandatanda kebesaran-Nya kepada orangorang yang mengetahui.

Ayat ini diperuntukkan untuk orang-orang yang bertakwa dan mereka yang mengetahui manfaat dari ilmu pengetahuan, dikarenakan hanya mereka yang terpelajar dan tunduk kepada kebesaran Allah saja yang dapat mengambil manfaat dari nikmat Allah tersebut. Di dalam ayat ini terkandung anjuran untuk mempelajari ilmu pengetahuan, karena Allah swt tidak menciptakan semua kebenaran melainkan untuk menunjukkan kekuasaan dan keesaan-Nya kepada manusia. Ilmu pengetahuan yang (c) 2020 STIE TDN. All rights reserved 
dianugerahkan kepada manusia merupakan hal yang sifatnya sangat dalam, di mana hal ini menjadi dasar pelaporan dan pencatatan yang harus dituliskan dengan benar dan tidak dimanipulasi, agar generasi selanjutnya dapat mengetahui kebenaran nikmat anugerah tersebut dan mendapatkan tanda-tanda kebesaran Allah di dalamnya.

2. Cepat Perhitungannya

Pelaporan dan pencatatan keuangan merupakan hasil dari proses akuntansi yang dapat digunakan sebagai alat komunikasi antara data keuangan suatu perusahaan dengan pihak yang berkepentingan terhadap data tersebut atau aktivitas perusahaan. Melalui laporan keuangan, pelaku usaha dapat menggunakan sebagai rujukan untuk mengetahui apakah bisnis yang dijalankannya berada dalam jalur yang tepat dan bermanfaat untuk orang lain. Itulah sebabnya, tindakan pencatatan dan pelaporan laporan keuangan yang berlandaskan akan kejujuran dan amanah akuntan pembuatnya sangat penting dalam menghasilkan laporan yang tepat guna.

Allah swt berfirman dalam QS Ali Imran/3: 19 yang berbunyi:

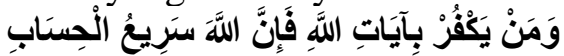

Terjemahan:

...wa may yakfur bi āyātillāhi fa innallāha sarī'ul-hisisāb.

...Barang siapa ingkar terhadap ayat-ayat Allah, maka sungguh, Allah sangat cepat perhitunganNya.

Allah swt juga berfirman dalam QS al-Maidah/5: 4 yang berbunyi:

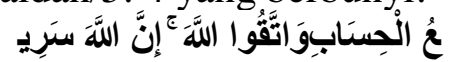

Terjemahan:

...wattaqullāh, innallāha sarī'ulhisāb.

...Dan bertakwalah kepada Allah, sungguh, Allah sangat cepat perhitungan-Nya.

Lalu, Allah swt juga berfirman dalam QS ar-Ra'd/13: 41 yang berbunyi:

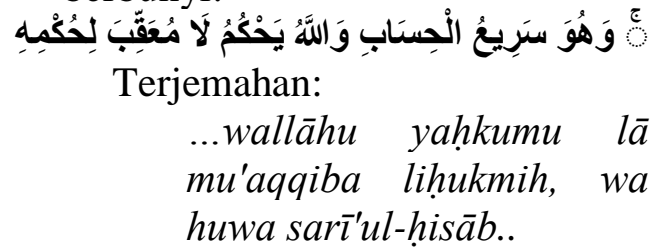

...Dan Allah menetapkan hukum (menurut kehendakNya), tidak ada yang dapat menolak ketetapan-Nya; Dia Mahacepat perhitungan-Nya.

Ketiga ayat tersebut di atas menunjukkan bukti bahwa Allah telah menetapkan hukuman atas konsekuensi yang dilakukan manusia jika mereka berani berbuat ingkar terhadap pertanggungjawaban pencatatan laporan keuangan yang mereka buat. Allah akan membalas perbuatan yang mencederai kejujuran dan menyesatkan masyarakat atas tindakan mereka. Sesungguhnya balasan Allah sangat adil dan cepat perhitungannya.

3. Dibuat oleh Ahlinya (Akuntan)

Umat Islam memiliki keharusan untuk meningkatkan kapasitas dan kualitas diri dari segala segi. Hal ini dilakukan untuk mempersiapkan sumber daya yang bermanfaat di semua lini kehidupan. Namun, dalam upaya mencapai peningkatan kapasitas tersebut ada kalanya manusia belum mencapai usaha yang maksimal, sehingga untuk mencapai tujuan yang diinginkan hendaklah pelaku usaha menyerahkan suatu perkara kepada orang yang lebih berilmu atau kepada orang yang telah paham dan ahli di bidangnya. Dalam hal ini, menyerahkan pencatatan pelaporan keuangan kepada seorang akuntan yang telah memiliki keahlian di dalamnya.

Allah swt berfirman dalam QS alAnkabut/29: 43 yang berbunyi:

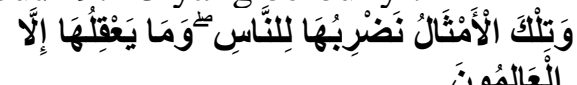

Terjemahan:

Wa tilkal-amsīàlu naḍibuhā

lin-nās, wa mā ya'qiluhā illal-'ālimụn.. (C) 2020 STIE TDN. All rights reserved 
Dan perumpamaan-

perumpamaan ini Kami buat

untuk manusia; dan tiada yang

memahaminya kecuali orang-

orang yang berilmu.

Rasulullah saw bersabda

bahwa:

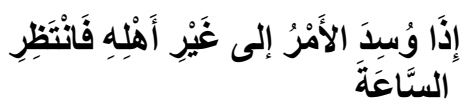

Terjemahan:

Apabila suatu perkara diserahkan kepada yang bukan ahlinya, maka tunggulah kehancurannya.

Dari ayat di atas dijelaskan bahwa betapa pentingnya untuk menyerahkan suatu masalah atau perkara kepada orang-orang yang telah teruji di bidangnya masing-masing. Menempatkan seseorang pada pekerjaan yang tepat dan sesuai dengan keahlian masing-masing sehingga mereka juga dapat mengembangkan potensinya secara maksimal. Urusan yang telah diserahkan kepada ahlinya pun merupakan suatu amanah dan tidak sepatutnya seorang ahli tersebut menghilangkan kepercayaan atas amanah yang telah diberikan kepadanya, karena akan mendatangkan kehancuran terhadap penyerahan sesuatu kepada yang bukan ahlinya.

4. Terang, Jelas, Tegas, Informatif, dan Dilakukan Secara Kontinyu

Dalam pembuatan laporan keuangan, hendaknya para pelaku usaha (atau melalui akuntannya) memberikan pencatatan yang sifatnya jelas, tegas, informatif, dan tidak ambigu. Hal ini dimaksudkan agar orang-orang yang mengakses dan membaca pelaporan tersebut mendapatkan pencerahan serta mendapatkan ilmu pengetahuan yang baru. Kejelasan dalam menuangkan pencatatan dalam laporan juga dapat digunakan sebagai metode pertanggungjawaban seorang akuntan terhadap amanah yang telah diberikan.

Allah swt berfirman dalam QS al-
Israa/17: 12 yang berbunyi:

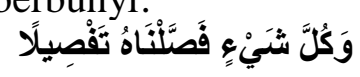

Terjemahan:

...wa kulla syai in fașsalnāhu tafșillā.

...Dan segala sesuatu telah Kami terangkan dengan jelas.

Mengacu pada ayat tersebut maka sebenarnya dapat ditemukan prinsipprinsip khusus dalam akuntansi syariah, yaitu keadilan, kebenaran, dan pertanggungjawaban. Oleh karena itu, nilai keadilan, kebenaran, dan pertanggungjawaban pencatatan transaksi dapat terwujud apabila pelaporan akuntansi dapat dilakukan dengan benar, cepat, terang, jelas, tegas, dan informatif; menyeluruh, ditujukan ke semua pihak; terperinci dan teliti, tidak terdapat unsur manipulasi, dan dilakukan secara berkesinambungan. Hal ini membuat pelaporan keuangan yang dibuat dapat dipercaya.

5. Informasi Ditujukan Kepada Semua Pihak yang Terlibat Secara Horizontal dan Vertikal serta Memuat Informasi yang Menyeluruh

Informasi menjadi sesuatu yang sangat penting dan dibutuhkan penggunanya dalam menambah wawasan dan pengetahuan. Tidak hanya kalangan tua, muda, kaya, dan miskin yang membutuhkan informasi, tetapi juga seluruh kalangan tanpa kecuali memandang informasi sebagai hal yang wajib dan penting untuk menentukan strategi yang tepat untuk melangkah. Maka dari itu, pencatatan laporan keuangan yang dibuat pelaku usaha hendaknya menganut prinsip informasinya dapat diakses oleh siapa saja.

Allah swt berfirman dalam QS an-Nisa'/4: 63 yang berbunyi:

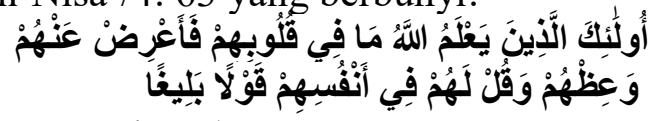

Terjemahan:

Ulā ikallażīna ya'lamullāhu mā (c) 2020 STIE TDN. All rights reserved

Corresponding Author: 80500218038@uin-alauddin.ac.id 
fi qulubihim fa a'rid 'an-hum wa'iz-hum wa qul lahum fi anfusihim qaulam balīgā.

Mereka itu adalah orang-orang yang Allah mengetahui apa yang di dalam hati mereka. Karena itu berpalinglah kamu dari mereka, dan berilah mereka pelajaran, dan katakanlah kepada mereka perkataan yang berbekas pada jiwa mereka.

Jika dikaitkan ayat di atas dengan pencatatan laporan keuangan yang memuat beragam informasi, dapat disimpulkan bahwa pelaku usaha diharuskan memberikan pelajaran dan pengetahuan tanpa memandang siapa mereka. pencatatan laporan keuangan tidak dibuat untuk golongan tertentu saja. Pencatatan laporan keuangan harus dilakukan secara komprehensif, menyeluruh, terperinci, dan teliti.

\section{Konsep Akuntansi dalam al-Quran}

Al-Quran memfokuskan proses pencatatan laporan keuangan pada uraian QS al-Baqarah/2: 282 yang menjelaskan tentang fungsi, dasar, dan manfaat pencatatan. Ilmu akuntansi sebagai perwujudan dari proses mencatat dan membukukan selanjutnya melaporkan harus diterapkan dalam setiap kehidupan sosial bermasyarakat. Allah swt berfirman:

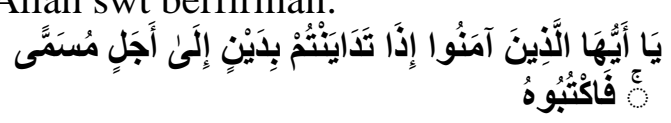

Terjemahan:

Yà ayyuhallażina āmanū iżā tadāyantum bidainin ilā ajalim musamman faktubụh...

Hai orang-orang yang beriman, apabila kamu bermuamalah tidak secara tunai untuk waktu yang ditentukan, hendaklah kamu menuliskannya.

Ayat tersebut diawali dengan panggilan kepada seluruh orang beriman yang melakukan transaksi muamalah dalam konteks pembiayaan.
Hal ini menunjukkan konsep identifikasi dalam proses akuntansi, di mana proses identifikasi merupakan proses awal akuntansi. Identifikasi ini akan memudahkan manusia ketika melakukan transaksi sehingga tidak ada yang merasa dirugikan atau merugikan.

Ayat ini juga membahas terkait muamalah, termasuk di dalamnya jual beli, utang piutang, dan sewa menyewa. Dari hal tersebut dapat ditarik kesimpulan bahwa Islam telah memerintahkan melakukan pencatatan yang ditekankan pada prinsip kebenaran, keterbukaan, keadila, dan kepastian di antara kedua belah pihak yang bertransaksi.

\section{METODE PENELITIAN}

\section{Jenis Penelitian}

Jenis penelitian ini menggunakan metode kualitatif dengan melakukan pendekatan studi literatur dari data sekunder, di mana data sekunder merupakan data yang diperoleh dari penelitian-penelitian yang telah dilakukan peneliti terdahulu dan sumber referensi lainnya. Data sekunder yang penulis gunakan merupakan bahan pustaka yang ditulis dan diterbitkan oleh seorang peneliti yang tidak secara langsung melakukan pengamatan atau turut berpartisipasi dalam kenyataan yang ia deskripsikan. Studi literatur merupakan pencarian terhadap berbagai sumber tertulis, baik berupa buku-buku, arsip, majalah, artikel, jurnal, dokumen, dan sumber lainnya yang relevan dengan permasalahan yang dikaji. Dalam penelitian ini, penulis mencoba menjelaskan tentang berbagai macam aliran pemikiran akuntansi syariah dari berbagai sumber.

\section{Metode Pengumpulan Data}

Metode pengumpulan data yang penulis gunakan dalam penelitian ini menggunakan teknik triangualsi teori 
(triangulation theory). Dalam teknik ini, peneliti memeriksa keabsahan data yang dimanfaatkan dengan cara melakukan pengecekan atau perbandingan terhadap data yang didapatkan. Tujuan penulis menggunakan teknik ini ialah untuk memeriksa kebenaran data, menyelidiki validitas tafsiran terhadap data, dan untuk memperkaya hasil penelitian sehingga penelitian ini dapat memberikan tambahan informasi bagi pihak yang membutuhkan.

\section{HASIL PENELITIAN DAN PEMBAHASAN}

Dalam perkembangannya di Indonesia, akuntansi syariah dibagi menjadi dua aliran, yaitu:

\section{Aliran Akuntansi Syariah Praktis}

Aliran akuntansi syariah praktis adalah praktik akuntansi pada lembaga keuangan syariah pada saat ini. Kemunculan berbagai lembaga keuangan syariah atau entitas yang menggunakan kegiatan syariah dalam transaksinya mengharuskan adanya praktik pencatatan untuk transaksitransaksinya. Namun, pada beberapa situasi dan kondisi, akuntansi syariah yang secara teori belum mampu untuk diterapkan lembaga atau entitas tersebut membuat mereka menerapkan ilmu akuntansi konvensional dengan menyesuaikan pada prinsip syariah.

Pendekatan yang digunakan dalam aliran akuntansi syariah praktis ini menggunakan pendekatan pragmatis, di mana pendekatan ini mengamati perilaku akuntansi secara terus menerus dengan tujuan untuk meniru prosedur dan prinsip-prinsip akuntansi. Pendekatan pragmatis terdiri dari penyusunan teori yang ditandai dengan penyesuaian praktik sesungguhnya yang bermanfaat untuk memberikan saran dan solusi praktis. Aliran ini lebih mengadaptasi pada teori akuntansi konvensional, mulai dari konsep dasar sampai ke bentuk teknologinya, tetapi disesuaikan dengan prinsip-prinsip Islam. Aliran akuntansi syariah praktis lebih banyak dilakukan dalam upaya mendapatkan sebuah format akuntansi syariah, dengan alasan kepentingan jangka pendek (pragmatis), yaitu biaya dan waktu. Dikarenakan menggunakan konsep akuntansi konvensional, maka aliran ini akan mengambil konsep yang tidak bertentangan dengan prinsip syariah.

Aliran ini dibangun atas dasar kebutuhan industri keuangan syariah. Pencetusnya adalah lembaga pembuat standar akuntansi syariah keuangan. Di dunia akuntansi internasional, pemikiran ini digunakan oleh Accounting and Auditing Standars For Islamic Financial Institutions (AAOFI) yang didirikan pada tahun 1998 di Bahrain. AAOIFI menjadi rujukan standar akuntansi untuk lembaga keuangan syariah di dunia. Di Indonesia sendiri, aliran akuntansi syariah praktis ini dimulai dengan adanya pembahasan terkait Baitul Mal Wat Tamwil (BMT) yang membahas konsep akuntansi dan kegiatan operasional di tahun 1999. Baru pada tahun 2003, Ikatan Akuntan Indonesia (IAI) mengesahkan secara resmi peraturan terkait akuntansi syariah pragmatis dengan menerbitkan PSAK 59 tentang Akuntansi Perbankan Syariah, dilanjutkan dengan pencabutan PSAK 59 tersebut pada tahun 2015 dan mengganti dengan PSAK 101-110 dikarenakan seiring waktu berjalan, PSAK 59 dirasa sudah tidak lagi sesuai dengan regulasi perbankan syariah saat ini dan Standar Akuntansi Keuangan pun sudah tidak lagi disusun berdasarkan industri atau jenis entitas tertentu, namun berdasarkan pada jenis transaksi pada laporan keuangan.

Aliran Akuntansi Syariah Filosofis- 


\section{Teoritis}

Aliran pemikiran akuntansi syariah filosofis-teoritis merupakan aliran pemikiran yang dibangun dari pendekatan deduktif-normatif. Pendekatan ini bermula pada konsep yang umum dan abstrak, kemudian diturunkan pada tingkat yang lebih konkrit dan pragmatis. Wacana ini mulai dari penetapan tujuan akuntansi, kemudian ke teori, dan akhirnya ke teknik akuntansi. Aliran ini mencoba merumuskan konsep akuntansi syariah yang bersumber dari nilai-nilai Islam.

Aliran akuntansi syariah ini memandang bahwa penggunaan akuntansi berbasis konvensional tidaklah cocok dan pantas untuk diterapkan dalam proses pengakuan pencatatan laporan keuangan untuk mereka yang menerapkan prinsip syariah dalam transaksinya. Menurut penganut aliran akuntansi ini, landasan filosofis akuntansi konvensional merupakan perwakilan pandangan kaum barat yang menjunjung tinggi prinsip kapitalis, sekuler, dan liberal. Penganut aliran ini juga memandang paradigma teori akuntansi konvensional hanya mementingkan laba semata, sehingga landasan filosofis seperti itu jelas akan sangat berpengaruh terhadap konsep dasar teori, praktik, hingga hasil akhirnya, yaitu laporan keuangan.

Penganut aliran ini tidak menyetujui konsep regulasi yang ditawarkan oleh para penganut akuntansi aliran praktis, di mana hal ini terlihat dari pandangan mereka yang keberatan dengan peraturan yang dikeluarkan Accounting and Auditing Standars For Islamic Financial Institutions (AAOFI) maupun PSAK 59 dan PSAK 101-110 yang dianggap masih menggunakan konsep akuntansi konvensional modern, seperti penyajian laporan laba rugi dan penggunaan going concern (prinsip kesinambungan usaha) dalam PSAK
59, di mana hal ini merupakan perwujudan akuntansi konvensional dunia barat.

Selain itu, penganut aliran ini merasa bahwa tujuan laporan keuangan akuntansi syariah dalam PSAK 59 hanya (dan masih) mengarah pada penyediaan informasi saja, di mana yang membedakan PSAK 59 dengan akuntansi konvensional ialah adanya tambahan informasi berkaitan pengambilan keputusan ekonomi dan kepatuhan terhadap prinsip syariah. Hal ini berbeda dengan pandangan penganut aliran akuntansi syariah filosofis-teoritis, di mana mereka berpandangan tujuan akuntansi syariah ada untuk mengarah kepada prinsip akuntabilitas yang lebih luas. Tujuan akuntansi syariah aliran ini ialah untuk membebaskan manusia dari ikatan jaringan kuasa kapitalisme atau jaringan kuasa lainnya yang semu, dan kemudian diikatkan pada jaringan kuasa ilahi. Dengan informasi yang dihasilkan oleh akuntansi syariah ini maka akan tercipta realitas tauhid, yaitu realitas yang sarat dengan jaring kuasa tauhid yang mendorong manusia pada kesadaran tauhid.

\section{KESIMPULAN}

Akuntansi syariah lahir dari nilainilai dan ajaran syariat Islam seiring dengan meningkatnya religiositas masyarakat Islam dan semakin banyaknya entitas ekonomi yang menjalankan usahanya berlandaskan prinsip syariah. Merupakan sebuah fenomena perkembangan akuntansi sebagai ideologi masyarakat Islam dalam menerapkan ekonomi Islami dalam kehidupan sosial-ekonominya. Akuntansi syariah merupakan bidang baru dalam kajian akuntansi yang memiliki karakteristik unik berbeda dengan akuntansi konvensional, karena mengandung nilai-nilai kebenaran berlandaskan syariat Islam. Perolehan 
pengetahuan akuntansi syariah sebagai bagian dari ilmu akuntansi digali menggunakan pendekatan Islam.

Perkembangan akuntansi syariah aliran praktis sejatinya akan selalu lebih maju dari aliran akuntansi syariah filosofis-teoritis, dikarenakan aliran ini lebih mampu untuk menjawab tuntutan kebutuhan industri dalam jangka pendek, sehingga kajian-kajian akuntansi syariah praktis lebih banyak dan lebih diminati. Pengembangan akuntansi syariah sebagai bidang ilmu akuntansi masih tergolong baru dan memerlukan proses ilmiah yang panjang jika dibandingkan dengan ilmu akuntansi itu sendiri. Penyempurnaan ilmu akuntansi syariah aliran apa pun tentunya memerlukan proses dan dukungan beragam pihak untuk menjadi bidang ilmu yang sempurna. Wallahu a'lam bis-shawabi.

DAFTAR PUSTAKA

Antonio, M. Syafi'i. "Bank Syariah: Dari Teori ke Praktik" (Cet. 1: Jakarta: Gema Insani Press, 2004): h. 1-256.

Apriyanti, Hanu Werdi. "Akuntansi Syariah: Sebuah Tinjauan Antara Teori dan Praktik", Jurnal Akuntansi Indonesia, Vol. 6, No. 2, (Juli 2017): h. 131-140.

Baydoun, Nabil dan Roger Willett. "Islamic Accounting Theory". Makalah yang disajikan pada Konferensi Tahunan Accounting and Finance Association of Australia and New Zealand (AAANZ) di Wollongong, Australia, 3-6 Juli 1994.

Budiman, Septian Arief. "Akuntansi dan Al-Quran", Jurnal Ilmiah Akuntansi Universitas Pamulang, Vol. I, No. I, (2018): h. 1-4.

Damsyiqi, Ibnu Hamzah al-Husaini alHanafi. "Asbabul Wurud".
Terj. M. Suwarta Wijaya dan Zafrullah Salim, Asbabul Wurud. Jakarta: Kalam Mulia, 2007.

Departemen Agama RI, “Al-Qur'an Transliterasi Latin Terjemahan Indonesia" (Cet. IV; Jakarta Timur: PT Suara Agung, 2012): h. 1-1500.

Gambling, Trevor dan Rifaat Ahmed Abdel Karim. "Business and Accounting Ethics in Islam" (Cet. 1; London: Mansell Publishing Ltd. 1991): h. 1152.

Hadi, Dudi Abdul. "Pengembangan Teori Akuntansi Syariah di Indonesia", Jurnal Akuntansi Multiparadigma (JAMAL), Vol. 9, N0. 1 (April 2018): h. 106123.

Hadjar, Ibnu. "Dasar-Dasar Metodologi Penelitian Kuantitatif Dalam Penelitian" (Cet. I; Jakarta: Raja Grafindo Persada, 1996): h. 1-298.

Hasnidar. "Akuntansi Syariah: Pendekatan Sejarah", Jurnal Akuntansi Barelang, Vol. 2, No. 1, (2017): h. 36-46.

Hisamduddin, Nur. "Persepsi Mengenai Wajar dan Benar dalam Penyajian Laporan Keuangan Entitas Syariah, Jurnal Akuntansi Universitas Jember, Vol. 11, No. 2, (2013): h. 62-77.

Ikatan Akuntan Indonesia. "Pencabutan PSAK 59: Akuntansi Perbankan Syariah" (Cet. I; Dewan Standar Akuntansi Syariah Ikatan Akuntan Indonesia: Jakarta, Oktober 2015): h. 1-10.

Kariyoto. "Akuntansi Syariah dalam Perspektif Teori dan Implementasinya", Jurnal JIBEKA, Vol. 8, No. 2, (Agustus 2014): h. 19-26.

Mauludi, Ali. "Akuntansi Syariah; (c) 2020 STIE TDN. All rights reserved 
Pendekatan Normatif, Historis, dan Aplikatif”, Jurnal Iqtishadia, Vol. 1, No. 1, (Juni 2014): h. 59-75.

Moleong, Lexy J. "Metode Penelitian Kualitatif" (Cet. I; Bandung: Remaja Rosdakarya, 2009): h. 1-424.

Muddatstsir, Uun Dwi Al dan Early Ridho Kismawadi. "Akuntan Syariah di Era Modern, Urgent Kah di Indonesia?", Jurnal Ihtiyadh, Vol. 1, No. 1, (September 2017): h. 23-36.

Muhamad. "Penyesuaian Teori Akuntansi Syari'ah: Perspektif Akuntansi Sosial dan Pertanggungjawaban", Iqtisad Journal of Islamic Economics, Vol. 3, No. 1, (2002): h. 67-87.

Mulawarman, Aji Dedi, dkk. "Menuju Teori Akuntansi Syariah Baru", Jurnal Ekonomi dan Keuangan Islam, Vo. 1, No. 1, (Januari 2011): h. 61-78.

Pratama, Bima Cinintya, dkk. "Penerapan Praktek dan Teori Akuntansi Syariah Berdasarkan Prinsip Syariah", AKUISISI: Journal of Accounting and Finance, Vol. 13, No. 2, (2017): h. 83-91.

Qardawi, Yusuf. "Islam Agama Perdaban" (Cet. I; Solo: Era Intermedia, 2004): h. 1-398.

Ratmono, Dwi dan Nur Cahyonowati. "Persistensi Relatif Earnings dan Anomali Pasar Berbasis Earnings". Makalah yang disajikan pada Simposium Nasional Akuntansi VII di Universitas Udayana, Bali, 2004.

Riyansyah, Ahmad. "Pemikiran Sofyan Syafri Harahap Tentang Akuntansi Syariah dan Penetapannya", At-Tafahum: Journal of Islamic Law, Vol. 1, No. 2, (Juli-Desember 2017): h. 12-24.
Sari, Nurma. "Akuntansi Syari'ah", Jurnal Khatulistiwa - Journal of Islamic Studies, Vol. 4, No. 1, (Maret 2014): h. 28-44.

Sawarjuwono, Tjiptohadi, Basuki Basuki, dan Iman Harymawan. "Menggali Nilai, Makna, dan Manfaat Perkembangan Sejarah Pemikiran Akuntansi Syariah di Indonesia", Jurnal JAAI, Vol. 15, No. 1, (Juni 2011): h. 6582.

Siregar, Budi Gautama. "Implementasi Akuntansi dalam Kehidupan Menurut Perspektif Islam", Jurnal Al-Masharif, Vol. 3, No. 1, (Januari-Juni 2015): h. 1-16.

Sitompul, Mhd. Syahman, Nurlaila, dan Hendra Harmain. "Implementasi Surat alBaqarah Ayat 282 dalam Pertanggungjawaban Mesjid di Sumatera Timur", Jurnal Human Falah, Vol. 3, No. 2, (Juli-Desember 2016): h. 203225.

Septiana, Yolanda. "Perlakuan Zakat Perusahaan dalam Laporan Keuangan Entitas Syariah dari Perspektif Akuntansi Syariah", Journal of Islamic Business and Economics, Vo. 2, No. 2, (Desember 2008): h. 101-124.

Susilowati, Lantip. "Tanggung Jawab, Keadilan, dan Kebenaran Akuntansi Syariah", Jurnal AnNisbah, Vol. 03, No. 02, (April 2017): h. 295-320.

Triyuwono, Iwan. "Perspektif, Metodologi, dan Teori Akuntansi Syariah" (Cet. 2; Jakarta: Raja Grafindo Persada, 2006): h. 1-402.

Verdianti. "Pencatatan Transaksi dan Laporan Keuangan Pada Entitas Bisnis Islami”, Jurnal Akuntansi UNESA, Vol. 1, No. 1, (2012): 82-89.

Wartoyo. "Sejarah Pemikiran Akuntansi Syariah", Adzkiya (c) 2020 STIE TDN. All rights reserved 
Jurnal Hukum dan Ekonomi Syariah, Vol. 1, No. 1, (2013): h. $35-47$

Widodo, Hertanto, dkk. "Panduan Praktis Operasional Baitul Mal Wat Tamwil" (Cet. I; Bandung: Mizan, 1999): h. 1-272.

Yadiati, Winwin. "Teori Akuntansi Suatu Pengantar" (Cet. I; Jakarta: Prenada Media, 2015): h. 1-168.

Yuliana, Rita. "Pemetaan Penelitian Kinerja Bank Syariah dengan Menggunakan Informasi Keuangan", Jurnal Akuntansi Multiparadigma (JAMAL), Vol. 5, No. 1, (April 2014): h. 4155.

Zaki, Muhammad. "Meretas Akuntansi Berbasis Syariah (Menelusuri Jejak Akuntansi dalam Quran dan Sunnah serta Perkembangannya di Indonesia), Jurnal Nur ElIslam, Vol. 3, No. 1, (April 2016): h. 91-102 